\title{
PENGARUH JOB INSECURITY, TERHADAP KEINGINAN BERPINDAH KERJA DENGAN KEPUASAN KERJA DAN KOMITMEN ORGANISASIONAL SEBAGAI VARIABEL INTERVENING (Studi pada Karyawan Pertelevisian di Jakarta)
}

\author{
Gabriela Meta Paramastri Kuding \\ Universitas Multimedia Nusantara \\ metakuding@gmail.com \\ Ratnawati Kurnia \\ Universitas Multimedia Nusantara \\ ratna@umn.ac.id
}

\begin{abstract}
This study aims to obtain empirical evidence about the effect of job insecurity toward job turnover intentions with job satisfaction and organizational commitment as intervening variable

The samples in this study are employees who worked at the television industry in Jakarta. Sampling method used was convenience sampling. Tests used in this study are validity testing, reliability testing, the classic assumption testing, simple regression and path analysis testing.

Results of the first hypothesis toward showed that there was significant influence of job insecurity towards job turnover intentions. Result of this study showed that organizational commitment and job satisfaction were not intervening variable in the relations between job insecurity and job turnover intention.
\end{abstract}

Keyword: job insecurity, organizational commitment, job satisfaction, turnover intentions of the employees

\section{Pendahuluan}

Karyawan merupakan aset perusahaan, karena karyawan terlibat langsung dalam melaksanakan kegiatan perusahaan dengan memberikan jasa baik berupa pikiran maupun tenaga. Perusahaan perlu mengelola karyawan yang dimilikinya dengan baik, efektif dan efisien agar para karyawan memiliki komitmen organisasional yang tinggi. Upaya untuk meningkatkan komitmen organisasional yang dapat ditempuh salah satunya dengan memperhatikan kepuasan kerja karyawan dan memantau pemenuhan kebutuhan-kebutuhan yang diinginkan oleh karyawan. Sehingga kepuasan kerja karyawan dapat ditingkatkan, serta menekan keinginan berpindah kerja dan job insecurity yang mungkin akan dialami oleh karyawan.

Keinginan berpindah kerja (turnover intentions) merupakan fenomena penting dalam kehidupan berorganisasi. Tingkat turnover yang tinggi akan menimbulkan dampak negatif bagi organisasi. Keinginan berpindah kerja mencerminkan individu untuk meninggalkan organisasi dan mencari alternatif pekerjaan lain. Abelson (1987) dalam Lekatompessy (2003), mengatakan bahwa keinginan berpindah kerja dapat meliputi tindakan-tindakan penarikan 
diri yang terdiri dari beberapa komponen yang secara simultan muncul dalam individu berupa adanya pikiran untuk keluar, keinginan untuk mencari lowongan pekerjaan lain, dan adanya keinginan untuk meninggalkan organisasi.

Karyawan yang memiliki komitmen yang tinggi pada perusahaan akan memiliki keinginan kuat untuk tetap menjadi bagian dari perusahaan dan berusaha untuk mencapai tujuan perusahaan yang telah ditetapkan. Komitmen terhadap organisasi adalah indentifikasi diri seseorang pada suatu organisasi dan tujuannya, serta kehendak memelihara identitas organisasi dan pencapaian tujuan organisasi (Robbins, 2007 dalam Kurnia 2009).

Kepuasan kerja dalam teori motivasi Maslow menempati peringkat yang tinggi. Sebab kepuasan kerja berkaitan dengan tujuan manusia untuk merealisasikan dan mengaktualisasikan potensi dirinya dalam pekerjaan. Semakin tinggi kepuasan kerja makin positif sikapnya terhadap pekerjaannya (Robbins, 2007 dalam Kurnia 2009). Ketika seorang karyawan mengalami rasa kurang puas terhadap pekerjaaannya, karyawan dapat mengungkapkannya kedalam berbagai macam cara, misalnya selain meninggalkan pekerjaan, karyawan dapat mengeluh ,membangkang, mencuri barang milik organisasi, menghindari sebagian dari tanggung jawab pekerjaan mereka. Kepuasan kerja menggambarkan kegembiraan atau sikap emosi positif yang berasal dari pengalaman kerja seseorang (Judge dan Locke, 1993).

Job insecurity didefinisikan oleh Greenhalgh dan Rosenblatt (1984) dalam Utami (2008) merupakan ketidakberdayaan seseorang dalam mempertahankan kesinambungan yang diinginkan dalam kondisi kerja yang terancam. Iriana et.al., (2004) dalam penelitiannya mengungkapkan bahwa job insecurity berpengaruh negatif terhadap komitmen organisasional, kemudian komitmen organisasional berpengaruh positif terhadap keinginan berpindah kerja. Timbulnya rasa tidak nyaman dan terancam pada karyawan akan menyebabkan rendahnya kepuasan kerja dan komitmen organisasional pada tempat dia bekerja. Masalah ini juga dapat timbul pada industry pertelevisian yang menuntut karyawannya dapat berfikir kreatif dan memiliki ide-ide segar untuk diberikan kepada masyarakat yang membutuhkan hiburan dan informasi.

Batasan masalah dalam penelitian ini adalah para karyawan yang bekerja pada industri pertelevisian swasta di Indonesia khususnya yang berada di Ibu Kota Jakata, serta memiliki waktu kerja yang tidak menentu atau lebih dikenal dengan pola kerja shift (waktu kerja yang berubah-ubah) sesuai dengan ketentuan yang berlaku. Karyawan yang akan diteliti adalah karyawan yang bekerja di lapangan (luar kantor) dan yang dituntut memiliki kesigapan dan kreatifitas yang tinggi dalam melakukan pekerjaannya.

\section{Rumusan Masalah}

Berdasarkan batasan masalah penelitian, masalah yang akan diteliti adalah:

1. Apakah job insecurity mempunyai pengaruh terhadap keinginan berpindah kerja?

2. Apakah job insecurity mempunyai pengaruh terhadap keinginan berpindah kerja dengan kepuasan kerja sebagai intervening variable?

3. Apakah job insecurity mempunyai pengaruh terhadap keinginan berpindah kerja dengan komitmen organisasional sebagai intervening variable ? 


\section{Tinjauan Literatur dan Hipotesis}

\section{Keinginan Berpindah Kerja}

Penelitian mengenai tingkat keinginan perpindahan kerja sampai saat ini masih tetap merupakan topic yang penting dan terus berlanjut. Secara umum diyakini bahwa cukup banyak karyawan yang berpindah-pindah perusahaan dalam kurun waktu yang relatif singkat. Keinginan berpindah kerja didefinisikan sebagai intens (keinginan) seseorang untuk melakukan aktual (turnover) dari suatu organisasi (Sunjoyo, 2002 dalam Siswanti, 2006). Menurut Abelson (1987) dalam Andaryani (2006) keinginan untuk pindah kerja mengacu pada hubungannya dengan organisasi dan belum diwujudkan dalam tindakan pasti meninggalkan organisasi.

Keinginan berpindah kerja menurut Suwandi dan Indriantoro (1999) dalam Utami dkk (2008), mencerminkan keinginan individu untuk meninggalkan organisasi dan mencari alternatif pekerjaan lain. Sedangkan menurut Robbins (1996) turn over diartikan sebagai penarikan diri baik secara sukarela (voluntary) ataupun tidak (involuntary) dari organisasi. Abelson (1987) dalam Harif (2001), menyatakan sebagian besar karyawan yang meninggalkan organisasi karena alasan voluntary dapat dikategorikan atas perpindahan kerja sukarela yang dapat dihindarkan (avoidable voluntary turnover) dan perpindahan kerja yang tidak dapat dihindarkan (unavoidable voluntary turnover).

Hasil penelitian Dalton dan Toder (1993, dalam Rivai 2001) memberikan dukungan bahwa: "Dampak negatif perpindahan kerja adalah pada kualitas dan kemampuan untuk menggantikan (replaceability) individu yang meninggalkan atau keluar organisasi”. Tingkat perpindahan kerja yang tinggi akan menimbulkan dampak negatif bagi organisasi, seperti menciptakan ketidakstabilan terhadap kondisi tenaga kerja dan peningkatan biaya sumber daya manusia. Hal tersebut menjadikan organisasi tidak efektif karena perusahaan kehilangan karyawan yang berpengalaman dan perlu melatih kembali karyawan baru. Kerugian akibat berpindahnya pekerja sangat besar bagi perusahaan. Perusahaan harus mengeluarkan biaya untuk melakukan perekrutan karyawan baru. Secara langsung yang diderita perusahaan akibat tingginya tingkat perpindahan karyawan ini antara lain berupa waktu yang digunakan untuk rekrutmen, seleksi, dan pelatihan bagi pegawai atau karyawan baru, sedangkan yang ditanggung antara lain peningkatan beban kerja pada personil tertentu yang ditugaskan untuk mengambil alih pekerjaan yang ditinggalkan pejabatnya, munculnya goncangan organisasi yang dapat mempengaruhi moral kerja karyawan secara keseluruhan, dan juga citra perusahaan yang buruk akibat publisitas negatif high turnover rate tersebut. Beberapa kerugian lain yang dapat muncul antara lain tidak adanya atau kurangnya kepercayaan konsumen terhadap kemampuan karyawan yang baru direkrut, berkurang atau hilangnya kerjasama tim yang sudah terbentuk.

Masalah mengenai keinginan berpindah karyawan dipilih dalam penelitian ini karena tingginya tingkat perputaran terutama karyawan yang potensial menimbulkan berbagai potensi biaya pelatihan yang sudah diinvestasikan pada karyawan, tingkat kinerja yang harus dikorbankan serta biaya rekrutmen dan pelatihan kembali yang tidak sedikit dan tidak mudah yang akan ditanggung oleh pihak perusahaan. Hal ini sangat merugikan bagi perusahaan, apalagi usaha pada bidang industri pertelevisian yang jelas-jelas membutuhkan tenaga kerja yang terampil dan professional dalam bidangnya. Jika tingkat turnover karyawannya tinggi, maka ini akan menjadi tantangan bagi industri peretelevisian itu sendiri untuk memuaskan masyarakat yang menikmati tayangan yang disajikan. 


\section{Job Insecurity}

Job insecurity adalah kondisi dimana karyawan merasakan adanya kondisi yang serba tidak pasti yang melingkupi pekerjaannya di masa yang akan datang, reward yang didapat dan masa kerja. Job Insecurity merupakan suatu tingkat dimana para pekerja merasa pekerjaannya terancam dan merasa tidak berdaya untuk melakukan apa pun terhadap situasi tersebut. Job insecurity yang dirasakan terus menerus oleh karyawan dapat mempengaruhi kualitas kerja. Perasaan tidak aman akan membawa dampak pada job attitudes karyawan, penurunan komitmen, bahkan keinginan untuk berpindah kerja yang semakin besar. Untuk mengurangi persepsi tersebut diperlukan sikap hati-hati dalam implementasi, dan diperlukan adanya komunikasi, bahkan dalam pelaksanaan restrukturisasi dilakukan yang secara bertahap (Johnson 1996, dalam Kinnunen 2000). Job insecurity didefinisikan oleh Greenhalgh dan Rosenblatt (1984) dalam Endah (2008) merupakan ketidakberdayaan seseorang dalam mempertahankan kesinambungan yang diinginkan dalam kondisi kerja yang terancam. Karyawan yang mengalami tekanan job insecurity memiliki alasan rasional untuk mencari alternatif pekerjaan lain yang dapat mendukung kelanjutan dan memberikan rasa aman bagi kariernya.

Job Insecurity dirasakan tidak hanya disebabkan oleh ancaman terhadap kehilangan pekerjaan, tetapi juga kehilangan dimensi pekerjaan (Ashford dkk, 1989 dalam Chairul 2009). Joelsen dan Walquist (dalam Hartley, 1991) menyatakan bahwa Job Insecurity merupakan pemahaman individual pekerja sebagai tahap pertama dalam proses kehilangan pekerjaan, dimana pekerja yang mengalami tekanan berlebih atas pekerjaannya cenderung untuk mencari alternatif pekerjaan lain. Kenyataannya, populasi yang mengalami job insecurity adalah selalu dalam jumlah yang lebih besar dari pada pekerja yang benar-benar kehilangan pekerjaan (Chairul, 2009). Hartley (1991) menyatakan bahwa Job Insecurity dilihat sebagai kesenjangan antara tingkat security yang dialamai seseorang dengan tingkat security yang ingin diperolehnya.

Hasil penelitian Pasewark dan Strawser (1996) menunjukkan bahwa job insecurity merupakan salah satu faktor yang menyebabkan seseorang memilih bertahan dengan pekerjaannya atau tidak. Job Insecurity merupakan kondisi ketidakberdayaan untuk mempertahankan kesinambungan yang diinginkan dalam situasi kerja yang mengancam. Karyawan yang bekerja dalam perusahaan terkadang merasa tidak nyaman dalam bekerja sehingga mempengaruhi emosi, proses, pikiran dan kondisi fisik. Ketidaknyamanan merupakan salah satu ciri-ciri adanya job insecurity. Menurut Green (2003) job insecurity sebagai kegelisaan pekerjaan, yaitu sebagai suatu keadaan dari pekerjaan yang terus menerus dan tidak menyenangkan. Pegawai yang mengalami job insecurity dapat mengganggu semangat kerja sehingga efektifitas dan efisiensi dalam melaksanakan tugas tidak dapat diharapkan dan juga akan mengakibatkan turunnya produktivitas kerja. Akibat turunnya produktivitas tentu saja mempengaruhi keberlangsungan perusahaan.

Ada pula karyawan yang memiliki kontrak kerja namun merasa tidak aman seberapa lama kontrak itu bisa diperpanjang lagi. Kondisi yang tidak permanen karena adanya ketidakpastian pekerjaan dapat menimbulkan job insecurity terutama yang masih muda. Karyawan muda dan berasal dari kalangan sosial menengah ke atas serta memiliki keterampilan yang cukup sekalipun tetap merasakan ketidakpastian akan apa yang terjadi di masa depan.

Hasil penelitian Sorenson (1974) menunjukkan adanya gap yang cukup luas antara praktisi yang telah sukses atau berpengalaman dengan staf yang baru direkrut sehingga hubungan kepuasan kerja dengan job insecurity tidak signifikan disebabkan kesulitan mengukur tingkat kepuasan kerja pada staf yang masih relatif baru dan belum berpengalaman. Kesulitan mengukur tingkat kepuasan kerja tersebut disebabkan karena staf 
yang baru dan belum berpengalaman tersebut masih mencari identitas diri dan masih dalam taraf penyesuaian terhadap lingkungan kerja.

Hasil penelitian Intiyas Utami dkk (2008) menyatakan bahwa job insecurity mempunyai pengaruh positif dan signifikan terhadap keinginan berpindah kerja. Dengan demikian semakin tinggi job insecurity akan menyebabkan tingginya keinginan berpindah kerja. Dalam penelitian Suwandi dan Indriantoro (1999) dalam Utami dkk (2008) menunjukan bahwa job insecurity sebagai faktor yang secara langsung mempengaruhi keinginan berpindah kerja.

\section{Komitmen Organisasional}

Strategi management untuk meningkatkan komitmen organisasi karyawan dilakukan dengan menciptakan situasi yang mampu menumbuhkan perasaan memiliki pada setiap karyawan terhadap perusahaa tempat karyawan tersebut bekerja. Trisnaningsih (2002) mengemukakan bahwa suatu komitmen organisasi menunjukkan suatu daya dari seseorang dalam mengidentifikasikan keterlibatannya dalam suatu bagian organisasi. Oleh karena itu komitmen organisasi akan menimbulkan rasa ikut memiliki (sense of belonging) bagi pekerja terhadap organisasi. Komitmen karyawan yang tinggi berdampak positif pada perusahaan seperti meningkatnya produksi. Mathie dan Zajac, dalam Fatikha (2005) dalam penelitiannya mengatakan jika karyawan memiliki komitmen yang tinggi, maka perusahaan atau organisasi akan mendapatkan dampak positif seperti meningkatnya produksi, kualitas kerja dan kepuasan kerja serta menurunnya tingkat keterlambatan, absensi dan turn over.

Dalam sebuah komitmen terjadi ikatan yang mengarah kepada tujuan yang lebih luas, dalam hal ini tujuan organisasi. Steers dalam Kuntjoro (2002) mendefinisikan komitmen organisasi sebagai rasa identifikasi (kepercayaan terhadap nilai-nilai organisasi), keterlibatan (kesediaan untuk berusaha sebaik mungkin demi kepentingan organisasi) dan loyalitas (keinginan untuk tetap menjadi anggota organisasi yang bersangkutan) yang dinyatakan oleh seorang pegawai terhadap organisasinya. Komitmen karyawan pada organisasi dapat dijadikan sebagai salah satu jaminan untuk menjaga kelangsungan organisasi tersebut.

Meyer and Allen (1993) menegaskan bahwa seseorang bisa mempunyai pemahaman yang lebih baik mengenai hubungan karyawan dengan organisasi ketika ketiga bentuk komitmen dipertimbangkan bersama-sama. Dikemukakan oleh Meyer et.al. (1993) tiga komponen tentang komitmen organisasional :

1. Affective Commitment, terjadi apabila karyawan ingin menjadi bagian dari organisasi karena adanya ikatan emosional. Karena memang dia menginginkannya.

2. Continuance Commitment, muncul apabila karyawan tetap bertahan pada suatu organisasi karena membutuhkan gaji dan keuntungan-keuntungan lain, atau karena karyawan tersebut tidak menemukan pekerjaan lain. Dengan kata lain, karena dia membutuhkannya.

3. Normative Commitment, timbul dari nilai-nilai diri karyawan. Yang bertahan menjadi anggota organisasi karena ada kesadaran bahwa berkomitmen terhadap organisasi merupakan hal yang memang seharusnya dilakukan.

Menurut Utami dkk (2003) ketidakberdayaan karyawan dalam menghadapi kondisi kerja yang terancam, akan mengakibatkan ketidakpercayaan dan penolakan terhadap nilai dan tujuan organisasi. Penelitian Cotton dan Tuttle (1986) menemukan bahwa keseluruhan kepuasan kerja berpengaruh negative terhadap keinginan berpindah kerja. Tingginya komitmen organisasi seseorang, termasuk di dalamnya adalah komitmen kontinuan, salah satunya dipengaruhi oleh karakter organisasi yang mencakup kondisi kerja yang dialaminya. 
Rosenblatt dan Ruvio (1996) menyatakan dalam penelitiannya bahwa pada akhirnya kondisi job insecurity memiliki efek negatif terhadap komitmen organisasi serta prestasi kerja karyawan (dalam Yousef, 1998). Sedangkan Utami dkk (2003) dalam penelitiannya terdahulu menyatakan semakin rendah job insecurity yang dirasakan akan menyebabkan semakin tingginya komitmen organisasionalnya, dan kemudian menyebabkan rendahya keinginan berpindah kerja.

Poznanski \& Dennis (1997), menguji kembali penelitian Gregson (1992), yang mengindikasikan bahwa kepuasan kerja merupakan pertanda awal dari komitmen organisasional. Hasil penelitian dengan melakukan pengujian tambahan yang dilakukan melalui penjumlahan hubungan variabel terikat, hubungan sebab akibat dari komitmen organisasional dan kepuasan kerja lebih jelas dibandingkan hubungan sebab akibat dari kepuasan kerja dengan komitmen organisasional.

\section{Kepuasan Kerja}

Kepuasan kerja menggambarkan kegembiraan atau sikap emosi positif yang berasal dari pengalaman kerja seseorang (Judge dan Locke, 1993 dalam Novliadi 2009). . Kepuasan kerja adalah tanggapan emosi terhadap berbagai segi pekerjaan (Kreitner dan Kinicki, 2001). Sedangkan menurut Robin (2001) dalam Siswanti (2006) menyatakan kepuasan kerja sebagai suatu sikap umum individu terhadap pekerjaannya. Apabila sikap ini positif, maka karyawan dikatakan puas, sedangkan ketidakpuasan terjadi bila sikap karyawan adalah negatif. Banyak penelitian mengkonsepkan keinginan berpindah sebagai tanggapan psikologis dan pilihan perilaku individu. Ketidakpuasan dalam pekerjaan sering diindikasikan sebagai alasan yang paling utama bagi para pekerja untuk meninggalkan pekerjaannya. Ketidakpuasan kerja pada tenaga kerja karyawan dapat diungkapkan kedalam berbagai macam cara, misalnya selain meninggalkan pekerjaan, karyawan dapat mengeluh, membangkang, mencuri barang milik organisasi, menghindari sebagian dari tanggung jawab pekerjaan mereka.

Kepuasan kerja memiliki tiga dimensi yang menggambarkan karakteristiknya, yaitu mengungkapkan respon emosional terhadap situasi kerja, ditentukan oleh seberapa baik hasil yang dicapai sesuai dengan harapan, dan menunjukkan hubungan beberapa sikap yang saling terkait. Menurut Wexley dan Yukl (1977), kepuasan kerja adalah apa yang dirasakan karyawan menyangkut pekerjaannya. Perasaan itu merupakan sikap umum (generalized attitude) seseorang terhadap pekerjaannya, yang didasarkan atas penilaiannya terhadap aspek perkerjaannya.

Disamping itu terdapat sejumlah faktor yang dapat memicu kepuasan kerja (job satisfaction) yaitu meliputi faktor kerja, upah, promosi, supervisi, dan kondisi kerja (Quardtein, el.al, 1993 dalam Prastiti 2002) dimana organisasi berperan mewujudkan serta meminimalkan deskriminasi dan ancaman terhadap faktor-faktor pendukung tersebut. Karyawan yang merasa puas akan memiliki perasaan positif, senang, atau bahagia terhadap pekerjaan lain dan sebaliknya. Karena dengan perasaan tenang dan aman terhadap pekerjaannya dapat mendukung terwujudnya kepuasan kerja karyawan. Kepuasan kerja juga terbukti berpengaruh terhadap keinginan berpindah seseorang. Penelitian Cotton dan Tuttle (1986) menemukan bahwa keseluruhan kepuasan kerja berpengaruh negative terhadap keinginan berpindah. Hubungan antara kepuasan dan turnover secara konsisten ditemukan dalam studi yang mengambil tema mengenai turnover. Passewark dan Strawser (1996) menemukan bahwa kepuasan kerja dan keinginan berpindah mempunyai pengaruh langsung dan memiliki hubungan negatif. Lum, etal. (1998) menyimpulkan secara empiris bahwa ketidakpuasan kerja memiliki pengaruh yang tidak langsung terhadap turnover melalui pengaruh langsungnya terhadap komitmen organisasional. 
Penelitian terdahulu yang dilakukan oleh Utami dkk (2008) menyatakan bahwa job insecurity dapat berpengaruh langsung pada keinginan untuk berpindah kerja dan dapat pula berpengaruh tidak langsung yaitu dari job insecurity ke kepuasan kerja (sebagai variable intervening) lalu ke keinginan berpindah kerja. Paparan teoritis Greenhalgh dan Rosenblatt (1984) dalam Prastiwi (2002), menyatakan bahwa individu yang merasa terancam pekerjaannya memiliki alasan rasional untuk mencari alternatif pekerjaan lain yang di pertimbangkan lebih aman.

Kepuasan kerja sangat penting karena menyumbang keberhasilan organisasi, antara lain dapat meningkatkan produktivitas dengan produk dan pelayanan yang berkualitas, dan juga dapat menurunkan tingkat absensi. Disamping itu kepuasan kerja sangat penting karena dapat meningkatkan komitmen organisasi dan prestasi kerja. Komitmen organisasi mengharapkan produktivitas yang tinggi sehingga dapat meningkatkan dan menyebabkan terjadinya kepuasan kerja. Kepuasan kerja penting karena dapat meningkatkan komitmen organisasi dan prestasi kerja dan prestasi kerja.

\section{Perumusan Hipotesis}

$\mathrm{Ha}_{1} \quad$ : Job Insecurity berpengaruh signifikan terhadap keinginan berpindah kerja

$\mathrm{Ha}_{2}$ : Job insecurity berpengaruh signifikan terhadap keinginan berpindah kerja dengan kepuasan kerja sebagai intervening variable

Ha3 : Job insecurity berpengaruh signifikan terhadap keinginan berpindah kerja dengan komitmen organisasi sebagai intervening variable.

\section{Gambar 2.1}

Model Penelitian

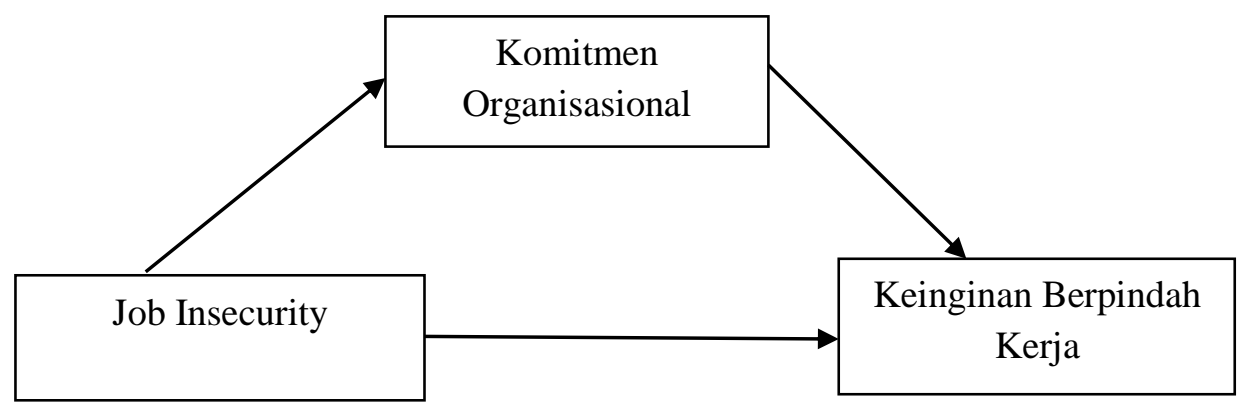

\section{III.Metode Penelitian}

Objek penelitian adalah karyawan yang bekerja pada industri media pertelevisian di Indonesia yang area kerjanya dilapangan atau diluar kantor. Karyawan yang menjadi objek penelitian tersebut memiliki tuntutan kerja tinggi untuk menghasilkan ide dan karya kreatif guna menginformasikan dan menghibur masyarakat yang menyaksikan, serta membangun rasa loyalitas masyarakat terhadap stasiun televisi tersebut. Stasiun televisi yang dipilih menjadi sampel dalam penelitian ini ada lima yang tersebar di sekitar Ibu Kota Jakarta yaitu, Metro TV, TV One, Trans 7, Jak TV, dan SCTV.

Penelitian yang dilakukan adalah penelitian kausalitas. Uji pengaruh digunakan untuk mengetahui pengaruh dari variabel independen terhadap variabel dependen. Variabel independen dalam penelitian ini adalah job insecurity dalam suatu system organisasi. Job insecurity adalah derajad perasaan tidak aman dalam bekerja karena rasa khawatir menghadapi berbagai perubahan yang terjadi pada organisasi tempat karyawan tersebut 
bekerja. Instrumen penelitian berupa kuesioner diambil dari penelitian Greenhalgh dan Resenball (1984) dalam Haryono (2005), terdiri dari lima item pertanyaan dengan lima poin skala likert

Variabel dependen dalam penelitian ini adalah keinginan berpindah kerja karyawan, yaitu derajat kecenderungan sikap yang dimiliki oleh karyawan untuk mengundurkan diri secara sukarela dari pekerjaannya. Keinginan berpindah kerja diukur dengan menggunakan instrument kuesioner dari penelitian Brayfield dan Rothe (1951) dalam Utami (2006), yang terdiri dari tujuh buah pertanyaan dengan 5 poin skala likert

Dalam penelitian ini variable intervening adalah komitmen organisasional dan kepuasan kerja. Komitmen organisasi adalah derajat perasaan terikat individu terhadap organisasi dan ditampilkan dalam bentuk melibatkan diri secara aktif dalam segala bentuk aktivitas yang menunjang kemajuan dan keberlangsungan organisasi. Instrumen yang digunakan berupa kuesioner yang terdiri dari lima pertanyaan dengan lima poin skala likert, dikembangkan Meyer dan Allen (1981). Sedangkan kepuasan kerja adalah perasaan senang atau puas terhadap pekerjaan yang sedang dijalani. Instrumen terdiri dari lima item pertanyaan, diperoleh dari penelitian Kalber dan Forgarty (1995) dalam Haryono (2005).

Data yang digunakan adalah data primer yang dikumpulkan dengan penyebaran kuesioner dengan menemui responden secara langsung serta menghubungi langsung contact person pada masing-masing sampel penelitian yang telah dipilih. Keempat variabel tersebut diukur dengan menggunakan skala Likert dengan pemberian skor sebagai berikut: jawaban "sangat setuju" mendapat skor 5, "setuju" mendapat skor 4, "netral" mendapat skor 3, "tidak setuju" mendapat skor 2, dan "sangat tidak setuju" mendapat skor 1. Skala pengukuran instrumen menggunakan skala interval. Teknik pengambilan sampel menggunakan teknik convenience sampling atau sampel yang dipilih dengan pertimbangan kemudahan dalam pengambilan data. Pemilihan teknik convenience sampling ini digunakan dengan pertimbangan dari peneliti untuk memudahkan dalam proses perolehan data yang dibutuhkan.

\section{Teknik Analisis Data}

\section{Pengujian Kualitas Data}

a. Uji Validitas

Uji validitas digunakan untuk mengukur sah atau valid tidaknya suatu kuesioner. Suatu kuesioner dikatakan valid jika pertanyaan pada kuesioner mampu untuk mengungkapkan sesuatu yang akan diukur oleh kuesioner tersebut. Pengujian validitas yang digunakan adalah Korelasi Pearson.

\section{b. Uji Reliabilitas}

Uji reliabilitas menunjukkan sejauh mana suatu instrumen pengukuran dapat dipercaya untuk mengukur objek yang akan diukur. Suatu kuesioner dikatakan reliable atau andal apabila jawaban seseorang terhadap pernyataan adalah konsisten atau stabil dari waktu ke waktu. Pengujian reliabilitas yang digunakan adalah koefisien Cronbach Alpha ( $\alpha$ ).

\section{c. Uji Normalitas}

Model regresi yang baik adalah distribusi data normal atau mendekati normal (Santoso, 2003). Distribusi normal merupakan distribusi teoritis dari variable random yang kontinyu (Dajan, 1986). Kurva yang menggambarkan distribusi normal adalah kurva normal yang berbentuk simetris. Metode yang digunakan adalah dengan melihat normal probability plot yang membandingkan distribusi kumulatif dari distribusi normal. 


\section{Uji Asumsi Klasik}

Syarat agar dapat menggunakan persamaan regresi berganda adalah terpenuhinya asumsi klasik untuk mendapatkan nilai pemeriksa yang tidak bias dan efisien (Best Linear Unbias Estimator/BLUE) dari suatu persamaan regresi berganda dengan metode kuadrat terkecil (Least Squares) (Setiawan, 2009). Persyaratan asumsi klasik yang harus dipenuhi adalah:

\section{a. Uji Multikolinearitas}

Multikolinearitas adalah suatu keadaan terjadinya satu atau lebih variabel bebas yang berkorelasi sempurna atau mendekati sempurna dengan variabel bebas lainnya. Untuk mendeteksi ada tidaknya gejala multikolinearitas dapat dilihat dari Value inflation Factor (VIF) variabel bebas terhadap variabel terikat (Santoso 2003).

\section{b. Uji Autokorelasi}

Autokorelasi muncul karena observasi yang berurutan sepanjang waktu berkaitan satu sama lainnya. Model regresi yang baik adalah regresi yang bebas dari autokorelasi. Jika terjadi korelasi, maka dinamakan problem autokorelasi. Uji autokorelasi bertujuan untuk melihat apakah terjadi korelasi antara suatu periode $t$ dengan periode sebelumnya $(t-1)$. Teknik cara untuk menguji dan mendeteksi ada atau tidaknya Autokorelasi adalah dengan Uji DurbinWatson (DW test) (Ghozali, 2005).

\section{c. Uji Heteroskedatisitas}

Bertujuan untuk menguji apakah dalam model regresi terjadi ketidaksamaan variance dari residual satu pengamatan ke pengamatan yang lain. Salah satu cara untuk mendeteksi adanya heterokedastisitas adalah dengan menggunakan scatter plot yaitu ZPRED dengan residualnya SRESID.

\section{Uji Hipotesis}

\section{a. Uji Regresi Sederhana}

Analisis regresi linear sederhana dipergunakan untuk mengetahui pengaruh antara satu buah variabel bebas terhadap satu buah variabel terikat. Uji rergresi sederhana digunakan untuk menguji pengaruh job insecurity sebagai variabel independen terhadap keinginan berpindah kerja sebagai variabel dependennya pada hipotesis yang pertama.

\section{b. Uji Path Analysis}

Dalam pengujian variabel intervening digunakan metode uji analisi jalur atau path analysis. Path Analysis (analis jalur) merupakan perluasan dari teknik analisi regresi berganda. Path Analysis (analis jalur) ialah suatu teknik untuk menganalisis hubungan sebab akibat yang tejadi pada regresi berganda jika variabel bebasnya mempengaruhi variabel tergantung tidak hanya secara langsung tetapi juga secara tidak langsung (Retherford 1993). Tujuan path analysis adalah memberikan estimasi terhadap hubungan sebab akibat antara variabelvariabel yang diteliti. Disamping mengetahui hubungan, dengan path analysis peneliti akan mengetahui pengaruh secara langsung maupun pengaruh secara tidak langsung antar variabel tersebut. 


\section{IV.Hasil dan Pembahasan}

\section{Statistik Deskriptif Responden}

Data penelitian yang diolah adalah jawaban dari responden atas kuesioner yang telah dikirim kepada responden. Kuesioner yang dikirim memuat pertanyaan terkait dengan data diri responden, job insecurity, komitmen organisasional, kepuasan kerja, dan keinginan berpindah kerja karyawan. Pengiriman kuesioner dilakukan pada bulan Oktober 2010 pertengahan dan pengembaliannya diharapkan dua sampai tiga minggu setelah diterima oleh responden yang dituju. Proses pengumpulan data dilakukan kurang lebih tiga bulan, yaitu sampai pertengahan bulan Januari 2011. Hasil pengumpulan kuesioner dapat dilihat dari tabel sebagai berikut.

\section{Tabel 4.1}

Presentase Pengiriman dan Pengembalian Kuesioner

\begin{tabular}{|l|c|c|}
\hline \multicolumn{1}{|c|}{ Keterangan } & Jumlah & Presentase \\
\hline Jumlah kuesioner yang dikirim: & 200 & $100 \%$ \\
\hline Kuesioner yang kembali: & 130 & $65 \%$ \\
\hline Kuesioner tidak lengkap: & 20 & $10 \%$ \\
\hline Kuesioner yang dapat digunakan: & 110 & $55 \%$ \\
\hline
\end{tabular}

Jumlah kuesioner yang dikirim kepada lima stasiun televisi yang ada disekitar wilayah Jakarta berjumlah 200 buah kuesioner. Kuesioner tersebut dikirim ke stasiun televisi SCTV (Surya Citra Televisi), TV One, Trans 7, Jak TV, dan Metro TV. Jumlah kuesioner yang kembali sebanyak 130 buah. Kuesioner tersebut tidak dapat digunakan seluruhnya karena ada 20 kuesioner yang tidak sesuai dengan objek yang diteliti dan tidak lengkap dalam mengisi pernyataan dalam kuesioner, sehingga kuesioner yang dapat digunakan dalam penelitian ini sebanyak 110 kuesioner atau 55\% dari total seluruh kuesioner yang telah dibagikan.

\section{Statistik Deskriptif Variabel}

Pada perhitungan statistik deskriptif variabel, menunjukkan perhitungan dari keempat variabel, yaitu job insecurity, komitmen organisasional, kepuasan kerja, dan keinginan berpindah kerja karyawan sebagai berikut digambarkan pada tabel 2.

Tabel 4.2

Descriptive Statistics

\begin{tabular}{|l|r|r|r|r|r|}
\hline & \multicolumn{1}{|c|}{ N } & Minimum & Maximum & \multicolumn{1}{c|}{ Mean } & Std. Deviation \\
\hline Job Insecurity & 110 & 16 & 29 & 21.52 & 2.93 \\
\hline Komitmen Organisasional & 110 & 16 & 28 & 23.07 & 2.46 \\
\hline Kepuasan Kerja & 110 & 14 & 31 & 20.15 & 2.90 \\
\hline Keinginan Berpindah Kerja & 110 & 12 & 47 & 29.59 & 5.81 \\
\hline Valid N (listwise) & 110 & & & & \\
\hline
\end{tabular}

Pada variabel job insecurity memiliki jumlah nilai minimum sebesar 16 dan jumlah nilai maksimum sebesar 29. Variabel job insecurity juga memiliki rata-rata sebesar 21.52, memiliki standar deviasi sebesar 2.93. Kemudian, pada variabel komitmen organisasional memiliki jumlah nilai minimum sebesar 16 dan jumlah nilai maksimum sebesar 28. Variabel 
komitmen organisasional juga memiliki rata-rata sebesar 23.07, memiliki standar deviasi sebesar 2.46

Pada variabel kepuasan kerja memiliki jumlah nilai minimum sebesar 14 dan jumlah nilai maksimum sebesar 31. Variabel kepuasan kerja juga memiliki rata-rata sebesar 20.15, memiliki standar deviasi sebesar 2.90. Kemudian, pada variabel keinginan berpindah kerja memiliki jumlah nilai minimum sebesar 12 dan jumlah nilai maksimum sebesar 4 . Variabel keinginan berpindah kerja juga memiliki rata-rata sebesar 29.59, memiliki standar deviasi sebesar 5.81 .

\section{Uji Validitas}

Tabel 4.3

Hasil Analisis Validitas dengan Menggunakan Pearson Correlation

\begin{tabular}{|l|c|c|}
\hline \multicolumn{1}{|c|}{ Variabel } & Sig. (2-tailed) & Keterangan \\
\hline Job Insescurity & $0.000-0.001$ & valid \\
\hline Komitmen Organisasional & $0.000-0.002$ & valid \\
\hline Kepuasan Kerja & $0.000-0.036$ & valid \\
\hline Keinginan Berpindah Kerja & 0.000 & valid \\
\hline
\end{tabular}

Hasil dari uji Korelasi Pearson untuk menguji validitas data adalah pada variabel job insecurity memiliki Sig. (2-tailed) berkisar antara 0.000 sampai dengan 0.001. Hasil ini menunjukkan bahwa pernyataan pada variabel job insecurity adalah valid. Pada variabel komitmen organisasional dilakukan uji validitas dan didapatkan satu hasil yang tidak signifikan yaitu sebesar 0.758 pada item nomor 7 . Setelah item tersebut dikeluarkan, maka mendapatkan hasil Sig. (2-tailed) berkisar antara 0.000 sampai dengan 0.002. Hasil ini menunjukkan bahwa pernyataan pada variabel komitmen organisasional adalah valid.

Kemudian, pada variabel kepuasan kerja memiliki Sig. (2-tailed) berkisar antara 0.000 sampai dengan 0.036. Hasil ini menunjukkan bahwa pernyataan pada variabel kepuasan kerja adalah valid. Pada variabel keinginan berpindah kerja dilakukan uji validitas dan didapatkan satu hasil yang tidak signifikan yaitu sebesar 0.645 pada item nomor 9. Setelah item tersebut dikeluarkan, maka mendapatkan hasil Sig. (2-tailed) yaitu 0.000. Hasil ini menunjukkan bahwa pernyataan pada variabel komitmen organisasional adalah valid.

\section{Uji Reliabilitas}

Hasil pengujian Cronbach's Alpha dari job insecurity didapat dari pengujian reliabilitas terhadap 7 item pertanyaan dengan hasil Cronbach's Alpha dibawah 0,6. Karena hasil tersebut belum reliable, maka dilakukan uji ulang dengan mengeluarkan 3 item pertanyaan yaitu pertanyaan nomor 5, 6, dan 7. Dari hasil uji tersebut menghasilkan nilai Cronbach's Alpha sebesar 0,618 maka variabel tersebut dikatakan reliable. Hasil pengujian reliabilitas terhadap variabel komitmen organisasional yang memiliki 6 item pertanyaan menunjukkan nilai dibawah 0,6. Karena hasil tersebut belum reliable, maka dilakukan uji ulang dengan mengeluarkan 1 item pertanyaan yaitu pertanyaan nomer 5 . Dari hasil uji tersebut menghasilkan nilai Cronbach's Alpha sebesar 0,618 maka variabel tersebut dikatakan reliable.

Hasil pengujian Cronbach's Alpha dari kepuasan kerja didapat dari pengujian reliabilitas terhadap 7 item pertanyaan dengan hasil Cronbach's Alpha sebesar dibawah 0,6. Karena hasil tersebut belum reliable, maka dilakukan uji ulang dengan mengeluarkan 3 item 
pertanyaan yaitu pertanyaan nomer 1,3 , dan 4 . Dari hasil uji tersebut menghasilkan nilai Cronbach's Alpha sebesar 0,629 maka variabel tersebut dikatakan reliable. Hasil untuk variabel keinginan berpindah kerja dilakukan uji reliabilitas terhadap 10 item pertanyaan yang memiliki nilai 0,829. Maka variabel tersebut bisa dikatakan reliable.

\section{Tabel 4.4}

Hasil Uji Reliabilitas dengan Menggunakan Cronbach's Alpha

\begin{tabular}{|l|c|c|}
\hline \multicolumn{1}{|c|}{ Variabel } & $\begin{array}{c}\text { Cronbach's Alpha Based on } \\
\text { Standardized Items }\end{array}$ & N of Items \\
\hline Job Insecurity & 0.618 & 4 \\
\hline Komitmen Organisasional & 0.618 & 5 \\
\hline Kepuasan Kerja & 0.629 & 4 \\
\hline Keinginan Berpindah Kerja & 0.829 & 10 \\
\hline
\end{tabular}

Berdasarkan hasil uji reliabilitas yang dilakukan, didapatkan hasil Cronbach Alpha untuk variabel job insecurity, komitmen organisasional, kepuasan kerja dan keinginan berpindah kerja memiliki nilai Cronbach Alpha diatas 0,6. Maka data tersebut dapat dikatakan reliable (Nunnally, 1967).

\section{Uji Normalitas}

Metode yang digunakan adalah dengan melihat normal probability plot yang membandingkan distribusi kumulatif dari distribusi normal. Distribusi normal akan membentuk satu garis lurus diagonal, dan ploting data residual akan dibandingkan dengan garis diagonal. Jika distribusi data residual normal, maka garis yang menggambarkan data sesungguhnya akan mengikuti garis diagonalnya.

\section{Gambar 4.1}

Hasil Uji Normalitas Hipotesis 1, 2, dan 3

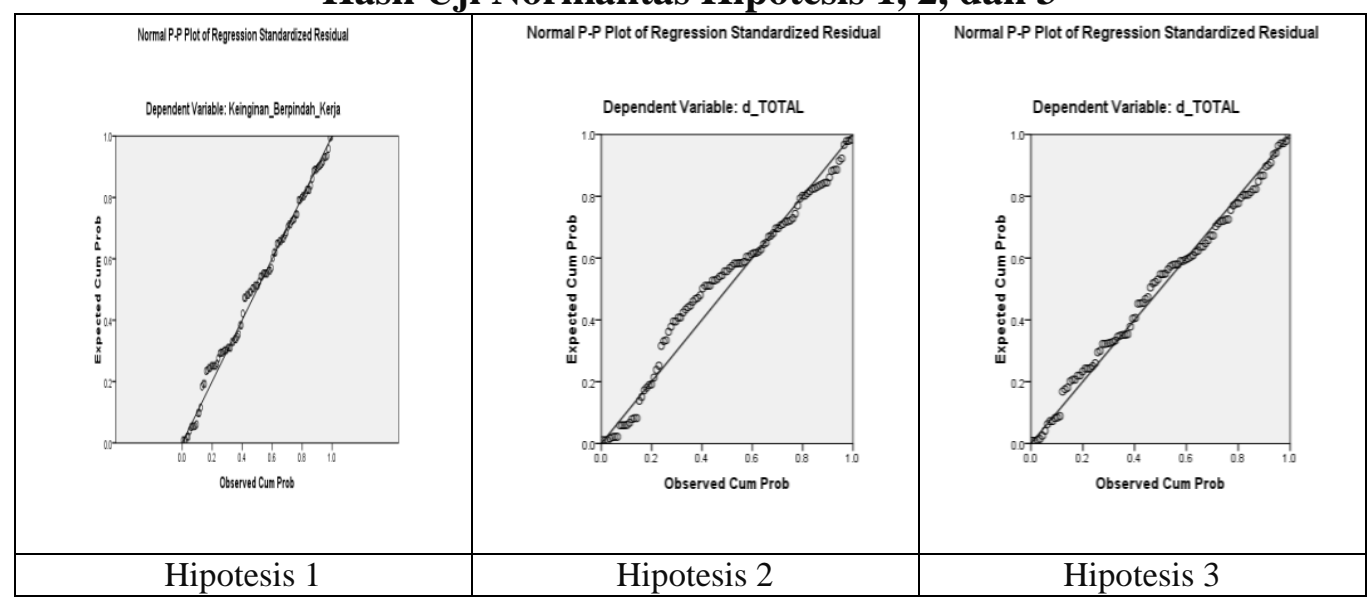

Hasil pengujian normalitas data menunjukkan bahwa data menyebar di sekitar garis diagonal dan mengikuti arah garis diagonal, maka model regresi tersebut telah memenuhi asumsi normalitas. 


\section{Uji Hipotesis}

\section{Uji Regresi Sederhana}

Tabel 4.5

Tabel Hasil Pengujian Regresi Sederhana Model Summary

\begin{tabular}{|c|c|c|c|c|}
\hline Model & $\mathrm{R}$ & R Square & $\begin{array}{l}\text { Adjusted R } \\
\text { Square }\end{array}$ & $\begin{array}{c}\text { Std. Error of the } \\
\text { Estimate }\end{array}$ \\
\hline 1 & 0,204 & 0,042 & 0,033 & 2,914 \\
\hline
\end{tabular}

Tabel 4.6

Tabel Hasil Pengujian Regresi Sederhana- Uji F

ANOVA $^{b}$

\begin{tabular}{|ll|c|c|c|c|c|}
\hline Model & & Sum of Squares & $\mathrm{df}$ & Mean Square & $\mathrm{F}$ & Sig. \\
\hline 1 & Regression & 40.012 & 1 & 40.012 & 4.712 & $.032^{\mathrm{a}}$ \\
& Residual & 917.043 & 108 & 8.491 & & \\
& Total & 957.055 & 109 & & & \\
\end{tabular}

a. Predictors: (Constant), Job_Insecurity

c. Dependent Variable: Keinginan Berpindah Kerja

Tabel 4.7

Tabel Hasil Pengujian Regresi Sederhana- Uji t

Coefficientsa

\begin{tabular}{|l|l|r|r|r|r|r|}
\hline \multirow{2}{*}{ Model } & \multicolumn{2}{|c|}{ Unstandardized Coefficients } & $\begin{array}{c}\text { Standardized } \\
\text { Coefficients }\end{array}$ & \multirow{2}{*}{$\mathrm{t}$} & \multirow{2}{*}{ Sig. } \\
\cline { 3 - 5 } & \multicolumn{1}{|c|}{$\mathrm{B}$} & Std. Error & \multicolumn{1}{c|}{ Beta } & & \\
\hline 1 & (Constant) & 18.348 & 3.274 & & 5.603 & 0.000 \\
& Job_Insecurity & 0.565 & 0.221 & 0.239 & 2.553 & 0.012 \\
\hline
\end{tabular}

a. Dependent Variable: Keinginan_Berpindah_Kerja

Hasil output SPSS (Tabel 4.5) model summary besarnya R Square adalah 0,042 atau sebesar 4,2\%. Hal ini berarti 4,2\% variasi keinginan berpindah kerja dapat dijelaskan oleh job insecurity dan sisanya 95,8\% dijelaskan oleh sebab-sebab lain diluar model. Berdasarkan hasil uji regresi tersebut didapatkan nilai signifikan 0.012 pada tabel uji ANOVA yang menandakan model regresi job insecurity berpengaruh signifikan terhadap keinginan berpindah kerja.

Sedangkan untuk hasil pengujiannya dapat dilihat dari nilai signifikan sebesar 0.032 dimana lebih kecil dari 0.05 yang menandakan uji regresi tersebut mempunyai pengaruh signifikan antara job insecurity dengan keinginan berpindah kerja. Hasil ini menunjukkan bahwa Hal tidak berhasil ditolak atau job insecurity memiliki pengaruh yang signifikan terhadap keinginan berpindah kerja 
Uji Path Analysis

1. Hipotesis 2

Tabel 4.8

Tabel Hasil Uji Path Analisis Persamaan 1

Model Summary ${ }^{b}$

\begin{tabular}{|l|r|r|r|r|}
\hline Model & $\mathrm{R}$ & R Square & Adjusted R Square & \multicolumn{1}{c|}{$\begin{array}{c}\text { Std. Error of the } \\
\text { Estimate }\end{array}$} \\
\hline 1 & $.204^{\mathrm{a}}$ & .042 & .033 & 2.91396 \\
\hline
\end{tabular}

a. Predictors: (Constant), Job_Insecurity

b. Dependent Variable: Komitmen_Organisasional

Tabel 4.9

Tabel Hasil Uji Path Analisis Persamaan 1ANOVA $^{b}$

\begin{tabular}{|ll|r|r|r|r|r|}
\hline Model & & Sum of Squares & df & Mean Square & F & Sig. \\
\hline 1 & Regression & 40.012 & 1 & 40.012 & 4.712 & $.032^{\mathrm{a}}$ \\
& Residual & 917.043 & 108 & 8.491 & & \\
& Total & 957.055 & 109 & & & \\
\hline
\end{tabular}

a. Predictors: (Constant), Job_Insecurity

b. Dependent Variable : Komitmen Organisasional

Tabel 4.10

Tabel Hasil Uji Path Analisis Persamaan 1-

Coefficientsa

\begin{tabular}{|c|c|c|c|c|c|c|}
\hline \multirow{2}{*}{\multicolumn{2}{|c|}{ Model }} & \multicolumn{2}{|c|}{$\begin{array}{l}\text { Unstandardized } \\
\text { Coefficients }\end{array}$} & \multirow{2}{*}{$\begin{array}{c}\text { Standardized } \\
\text { Coefficients }\end{array}$} & \multirow[t]{2}{*}{$t$} & \multirow[t]{2}{*}{ Sig. } \\
\hline & & $\mathrm{B}$ & Std. Error & & & \\
\hline \multirow[t]{2}{*}{1} & (Constant) & 9.248 & 1.676 & & 5.517 & 0.000 \\
\hline & Job Insecurity & 0.246 & 0.113 & 0.204 & 2.171 & 0.032 \\
\hline
\end{tabular}

a. Dependent Variable: Komitmen_Organisasional

Hasil output SPSS (Tabel 4.10) memberikan nilai Unstandardized Coefficients Beta job insecurity sebesar 0.246 yang merupakan nilai jalur path p2. Dengan R Square sebesar 0.042 akan didapat e1 $=(1-\mathrm{R} \text { Square })^{2}=(1-0.042)^{2}=(0.958)^{2}=0.918$ yang merupakan jumlah variance variabel komitmen organisasional yang tidak dapat dijelaskan oleh variabel job insecurity.

Tabel 4.11

Tabel Hasil Uji Path Analisis Persamaan 2

\begin{tabular}{|l|r|r|r|r|}
\hline \multicolumn{1}{|c|}{ Model Summary $^{\mathbf{b}}$} \\
\hline 1 & $\mathrm{R}$ & \multicolumn{1}{c|}{ R Square } & \multicolumn{1}{c|}{ Adjusted R Square } & \multicolumn{1}{c|}{$\begin{array}{c}\text { Std. Error of the } \\
\text { Estimate }\end{array}$} \\
\hline & $.489^{\mathrm{a}}$ & .239 & .225 & 5.13783 \\
\hline
\end{tabular}

a. Predictors: (Constant), Komitmen_Organisasional, Job_Insecurity

b. Dependent Variable: Keinginan_Berpindah_Kerja 
Tabel 4.12

Tabel Hasil Uji Path Analisis Persamaan 2

\begin{tabular}{|ll|r|r|r|r|r|}
\hline \multicolumn{1}{|c|}{ ANOVA $^{\mathrm{b}}$} & \multicolumn{1}{c|}{ Sig. } \\
\hline 1 & & Sum of Squares & Df & Mean Square & F & \multicolumn{1}{c|}{. } \\
& Regression & 886.078 & 2 & 443.039 & 16.783 & \\
& Residual & 2824.512 & 107 & 26.397 & & \\
& Total & 3710.591 & 109 & & & \\
\hline
\end{tabular}

a. Predictors: (Constant), Komitmen_Organisasional, Job_Insecurity

b. Dependent Variable: Keinginan_Berpindah_Kerja

Tabel 4.13

Tabel Hasil Uji Path Analisis Persamaan 2

Coefficientsa

\begin{tabular}{|l|l|r|r|r|r|r|}
\hline \multirow{2}{*}{ Model } & \multicolumn{2}{|c|}{$\begin{array}{c}\text { Unstandardized } \\
\text { Coefficients }\end{array}$} & $\begin{array}{c}\text { Standardized } \\
\text { Coefficients }\end{array}$ & \multicolumn{1}{c|}{$\mathrm{t}$} & \multirow{2}{*}{ Sig. } \\
\cline { 3 - 5 } \multicolumn{2}{|c|}{} & \multicolumn{1}{c|}{ B } & Std. Error & \multicolumn{1}{|c|}{ Beta } & & \\
\hline 1 & (Constant) & 10.414 & 3.346 & & 3.112 & 0.002 \\
& Job_Insecurity & 0.354 & 0.204 & 0.149 & 1.735 & 0.086 \\
& Komitmen_Organisasional & 0.858 & 0.170 & 0.436 & 5.056 & 0.000 \\
\hline
\end{tabular}

a. Dependent Variable: Keinginan_Berpindah_Kerja

Untuk persamaan 2 didapatkan hasil output SPSS yang ada pada tabel 4.13. Hasil dari Unstandardized Coefficients Beta dari job insecurity sebesar 0.354 yang merupakan nilai dari jalur path $\mathrm{p} 1$ dan Unstandardized Coefficients Beta dari komitmen organisasional 0.858 sebagai p3. Dengan Adjusted R Square sebesar 0.225 akan didapat e3 $=(1-\mathrm{R} \text { Square })^{2}=(1-$ $0.225)^{2}=(0.775)^{2}=0.6$ yang merupakan jumlah variance variabel keinginan berpindah kerja yang tidak dapat dijelaskan oleh variabel job insecurity dan komitmen organisasional.

Gambar 4.2

Hasil Pengujian Path Analysis 1

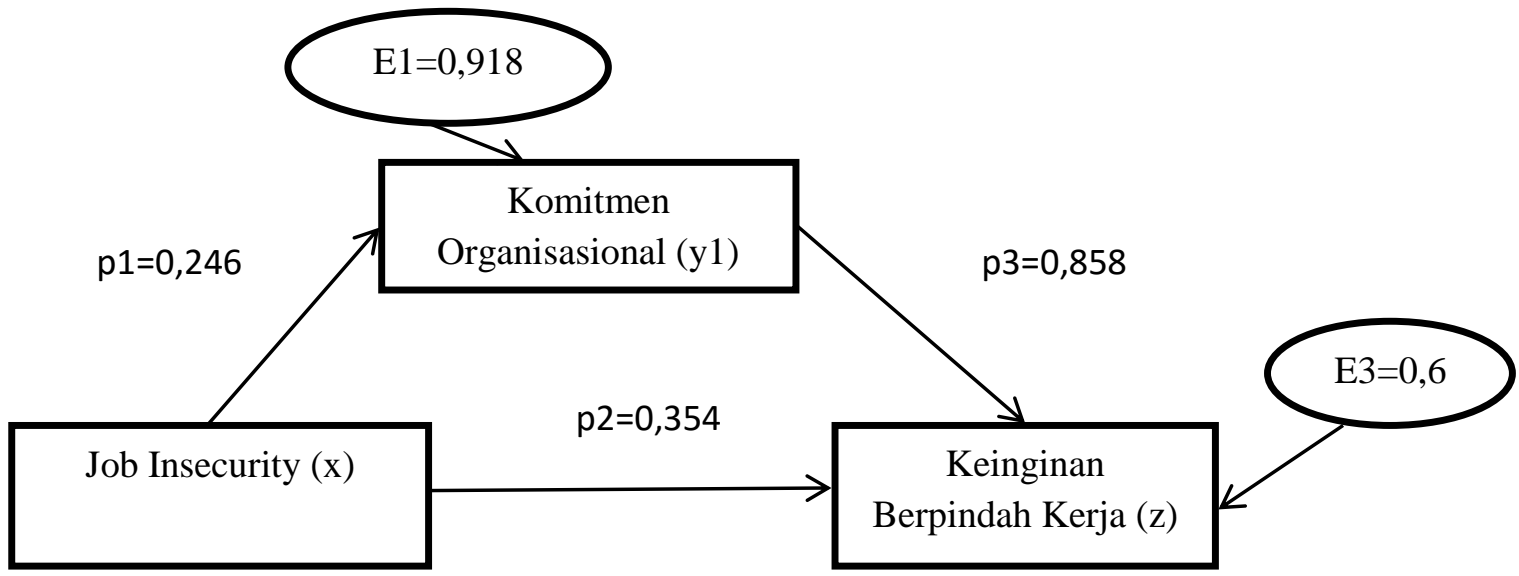


Hasil analisis jalur pada Gambar 4.2 menunjukan bahwa job insecurity dapat berakibat langsung terhadap keinginan berpindah kerja, maupun secara tidak langsung yaitu job insecurity melalui komitmen organisasional sebagai variabel intervening baru kepada keinginan berpindah kerja. Besarnya koefisien langsung job insecurity kepada keinginan berpindah kerja adalah sebesar p1 yaitu 0.354 sebagai hasil pengaruh langsung antara job insecurity dengan keinginan berpindah kerja. Sedangkan besarnya koefisien tidak langsung adalah hasil perhitungan $\mathrm{p} 2 \times \mathrm{p} 3=0.246 \times 0.858=0.211$ yang merupakan pengaruh tidak langsung dari job insecurity ke keinginan berpindah kerja melalui komitmen organisasional sebagai variabel interveningnya. Hasil total pengaruh korelasi job insecurity terhadap keinginan berpindah kerja adalah sebesar p1 $+(\mathrm{p} 2 \times \mathrm{p} 3)=0.354+0.211=0.565$

Pada hipotesis kedua, yaitu job insecurity berpengaruh signifikan kepada keinginan berpindah kerja melalui komitmen organisasional sebagai variabel interveningnya. Menunjukan hasil uji path analisis yang sudah dilakukan dan didapatkan nilai signifikan 0.000 pada tabel uji ANOVA yang menandakan model regresi job insecurity berpengaruh signifikan terhadap keinginan berpindah kerja melalui komitmen organisasional sebagai variabel interveningnya.

Sedangkan dari nilai perbandingan nilai langsung sebesar 0.3554 dan nilai tidak langsung sebesar 0.211 yang di dapatkan, nilai pengaruh langsung lebih besar dibanding nilai tidak langsung yang menggunakan komitmen organisasional sebagai variabel interveningnya.Hasil tersebut dapat disimpulkan bahwa Ha2 yang menyatakan bahwa job insecurity berpengaruh tidak langsung terhadap keinginan berpindah kerja dengan komitmen organisasional sebagai variabel interveningnya berhasil ditolak.

\section{Hipotesis 3}

Tabel 4.14

Tabel Hasil Uji Path Analisis Persamaan 1

Model Summaryb

\begin{tabular}{|l|r|r|r|c|}
\hline Model & $\mathrm{R}$ & $\mathrm{R}$ Square & \multicolumn{1}{|c|}{$\begin{array}{c}\text { Adjusted R } \\
\text { Square }\end{array}$} & $\begin{array}{c}\text { Std. Error of the } \\
\text { Estimate }\end{array}$ \\
\hline 1 & $.149^{\mathrm{a}}$ & .022 & .013 & 2.24144 \\
\hline
\end{tabular}

a. Predictors: (Constant), Job_Insecurity

b. Dependent Variable: Kepuasan_Kerja

Tabel 4.15

Tabel Hasil Uji Path Analisis Persamaan 1 ANOVAb

\begin{tabular}{|l|l|r|r|r|r|r|}
\hline Model & & \multicolumn{1}{c|}{$\begin{array}{c}\text { Sum of } \\
\text { Squares }\end{array}$} & \multicolumn{1}{c|}{ df } & \multicolumn{1}{c|}{$\begin{array}{c}\text { Mean } \\
\text { Square }\end{array}$} & F & Sig. \\
\hline 1 & Regression & 12.392 & 1 & 12.392 & 2.466 & 0.119 \\
& Residual & 542.599 & 108 & 5.024 & & \\
& Total & 554.991 & 109 & & & \\
\hline
\end{tabular}

a. Predictors: (Constant), Job_Insecurity

b. Dependent Variable: Kepuasan_Kerja 
Tabel 4.16

Tabel Hasil Uji Path Analisis Persamaan 1

\begin{tabular}{|l|l|r|r|r|r|r|}
\hline \multicolumn{2}{|c|}{} & \multicolumn{2}{|c|}{$\begin{array}{c}\text { Unstandardized } \\
\text { Coefficients }\end{array}$} & $\begin{array}{c}\text { Standardized } \\
\text { Coefficients }\end{array}$ & \multirow{2}{*}{$\mathrm{t}$} & \multirow{2}{*}{ Sig. } \\
\cline { 3 - 8 } & \multicolumn{1}{|c|}{ B } & Std. Error & Beta & & 0.000 \\
\cline { 3 - 8 } & (Constant) & 12.812 & 1.289 & & 1.571 & 0.119 \\
\hline
\end{tabular}

a. Dependent Variable: Kepuasan_Kerja

Hasil output SPSS (Tabel 4.16) memberikan nilai Unstandardized Coefficients Beta job insecurity sebesar 0.137 yang merupakan nilai jalur path $\mathrm{p} 4$. Dengan R Square sebesar 0.022 akan didapat e2 $=(1-\mathrm{R} \text { Square })^{2}=(1-0.022)^{2}=(0,978)^{2}=0.956$ yang merupakan jumlah variance variabel kepuasan kerja yang tidak dapat dijelaskan oleh variabel job insecurity.

Tabel 4. 17

Tabel Hasil Uji Path Analisis Persamaan 2

Model Summary ${ }^{b}$

\begin{tabular}{|l|r|r|r|r|}
\hline Model & $\mathrm{R}$ & \multicolumn{1}{|c|}{ R Square } & Adjusted R Square & \multicolumn{1}{c|}{$\begin{array}{c}\text { Std. Error of the } \\
\text { Estimate }\end{array}$} \\
\hline 1 & $.389^{\mathrm{a}}$ & .151 & .135 & 5.42536 \\
\hline
\end{tabular}

a. Predictors: (Constant), Kepuasan_Kerja, Job_Insecurity

b. Dependent Variable: Keinginan_Berpindah_Kerja

Tabel 4. 18

Tabel Hasil Uji Path Analisis Persamaan 2 ANOVA

\begin{tabular}{|ll|r|r|r|r|r|}
\hline del & & Sum of Squares & df & Mean Square & F & Sig. \\
\hline 1 & Regression & 561.099 & 2 & 280.550 & 9.531 & $.000^{\mathrm{a}}$ \\
& Residual & 3149.492 & 107 & 29.435 & & \\
& Total & 3710.591 & 109 & & & \\
\end{tabular}

a. Predictors: (Constant), Kepuasan_Kerja, Job_Insecurity

c. Dependent Variable: Keinginan_Berpindah_Kerja 
Tabel 4. 19

Tabel Hasil Uji Path Analisis Persamaan 2

\begin{tabular}{|c|c|c|c|c|c|c|}
\hline \multicolumn{7}{|c|}{ Coefficientsa } \\
\hline \multicolumn{2}{|c|}{ Model } & \multicolumn{2}{|c|}{$\begin{array}{l}\text { Unstandardized } \\
\text { Coefficients }\end{array}$} & \multirow{2}{*}{$\begin{array}{c}\begin{array}{c}\text { Standardized } \\
\text { Coefficients }\end{array} \\
\text { Beta }\end{array}$} & \multirow[t]{2}{*}{$\mathrm{t}$} & \multirow[t]{2}{*}{ Sig. } \\
\hline & & B & Std. Eтто & & & \\
\hline \multirow[t]{3}{*}{1} & (Constant) & 28.637 & 4.318 & & 6.632 & 0.000 \\
\hline & Job_Insecurity & 0.674 & 0.213 & 0.285 & 3.164 & 0.002 \\
\hline & Kepuasan Keija & -0.803 & 0.233 & -0.311 & -3.448 & 0.001 \\
\hline
\end{tabular}

a. Dependent Variable: Keinginan_Berpindah_Kerja

Untuk persamaan 2 didapatkan hasil output SPSS menggambarkan hasil dari Unstandardized Coefficients Beta dari job insecurity sebesar 0.674 yang merupakan nilai dari jalur path p1 dan Standardized Coefficients Beta dari kepuasan kerja -0.803 sebagai p5. Dengan Adjusted R Square sebesar 0.135 akan didapat e3 $=(1-\mathrm{R} \text { Square })^{2}=(1-0.135)^{2}=$ $(0.865)^{2}=0.748$ yang merupakan jumlah variance variabel keinginan berpindah kerja yang tidak dapat dijelaskan oleh variabel job insecurity.

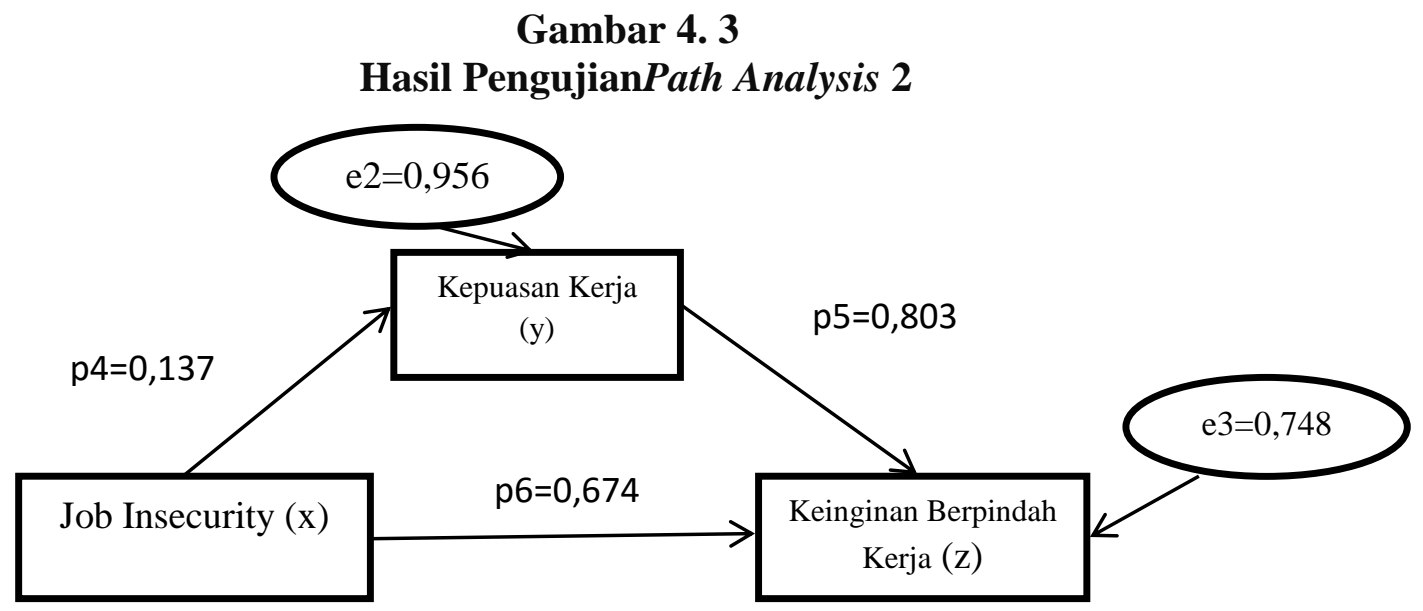

Hasil analisis jalur pada Gambar 4.3 menunjukan bahwa job insecurity dapat berakibat langsung terhadap keinginan berpindah kerja, maupun secara tidak langsung yaitu job insecurity melalui kepuasan kerja sebagai variabel intervening baru kepada keinginan berpindah kerja. Besarnya koefisien langsung job insecurity kepada keinginan berpindah kerja adalah sebesar p1 yaitu 0.674. Sedangkan besarnya koefisien tidak langsung adalah hasil perhitungan $\mathrm{p} 4 \times \mathrm{p} 5=0.137 \times-0.803=-0,11$. Maka total pengaruh korelasi job insecurity terhadap keinginan berpindah kerja adalah sebesar $\mathrm{p} 1+(\mathrm{p} 4 \mathrm{x} \mathrm{p5})=0.674+(-0.11)$ $=0.564$.

Pada hipotesis ketiga, yaitu job insecurity berpengaruh signifikan kepada keinginan berpindah kerja melalui kepuasan kerja sebagai variabel interveningnya. Berdasarkan hasil uji path analisis yang sudah dilakukan didapatkan nilai signifikan 0.000 pada tabel uji ANOVA yang menandakan model regresi job insecurity berpengaruh signifikan terhadap keinginan berpindah kerja melalui kepuasan kerja sebagai variabel interveningnya.

Sedangkan dari nilai perbandingan nilai langsung sebesar 0.674 dan nilai tidak langsung sebesar -0.11 yang di dapatkan, nilai pengaruh langsung lebih besar dibanding nilai tidak langsung yang menggunakan kepuasan kerja sebagai variabel interveningnya. Hasil 
tersebut dapat disimpulkan bahwa Ha3 yang menyatakan bahwa job insecurity berpengaruh tidak langsung terhadap keinginan berpindah kerja dengan kepuasan kerja sebagai variabel interveningnya berhasil ditolak.

\section{Simpulan, Keterbatasan, dan Saran}

\section{Simpulan}

Kesimpulan dari penelitian ini adalah:

1. Pada model hipotesis alternative pertama, dimana terdapat pengaruh yang signifikan antara job insecurity dengan keinginan berpindah kerja pada karyawan yang berkerja industry pertelevisian yang ditunjukkan dengan nilai signifikansi 0,005. Hasil ini menyatakan bahwa hipotesis alternatif 1 tidak berhasil ditolak. Konsisten dengan penelitian yang dilakukan oleh Suwandi dan Indriantoro (1999) yang menunjukan bahwa job insecurity sebagai factor yang secara langsung mempengaruhi keinginan berpindah kerja dan hasil penelitian Intiyas Utami dkk (2008) menyatakan bahwa job insecurity mempunyai pengaruh positif dan signifikan terhadap keinginan berpindah kerja.

2. Komitmen organisasional tidak dapat berperan sebagai variable intervening padajob insecurity terhadap keinginan berpindah kerja yang dirasakan oleh karyawan yang bekerja pada industry pertelevisian yang ditunjukan dengan nilai langsung dari job insecurity kepada keinginan berpindah kerja lebih besar jika dibanding dengan pengaruh tidak langsung dari komitmen organisasional sebagai interveningnya. Hal ini menyatakan bahwa hipotesis alternative kedua berhasil ditolak. Komitmen organisasional karyawan televisi dalam bekerja akan dapat berkembang searah dan seiring jalan dalam mewujudkan tujuan industry pertelevisian saat itu. Hasil ini konsisten dengan hasil penelitian dari Utami (2008) menyatakan bahwa pengaruh langsung job insecurity terhadap keinginan berpindah kerja lebih besar dibandingkan dengan pengaruh tidak langsung dengan komitmen organisasional sebagai variabel interveningnya.

3. Kepuasan kerja tidak berperan sebagai variable intervening pada job insecurity terhadap keinginan berpindah kerja yang dialami oleh karyawan. Ini dibuktikan dengan nilai dari koefisien jalur secara langsung antara job insecurity dengan kepuasan kerja lebih besar yang dibandingkan dengan job insecurity berpengaruh tidak langsung terhadap keinginan berpindah kerja melalui kepuasan kerja sebagai variabel interveningnya. Hal ini menyatakan bahwa hipotesis alternative ketiga berhasil ditolak. Ini sesuai dengan penelitian dari Utami (2008) yang menyatakan besarnya nilai pengaruh langsung lebih besar jika dibandingkan dengan hubungan tidak langsung yang menggunakan kepuasan kerja sebagai interveningnya.

\section{Keterbatasan}

Penelitian ini memiliki beberapa keterbatasan dalam pengambilan sampel, yaitu:

1. Keterbatasan penelitian ini adalah penelitian yang dilakukan dengan menggunakan metode survey melalui kuesioner. Kelemahan metode survey melalui kuesioner memungkinkan terjadinya bias oleh responden, tanggapan atas responden kemungkinan tidak sesuai dengan maksud dari pertanyaan dalam kuesioner, dan responden kemungkinan mengisi kuesioner dengan tidak lengkap. Dengan demikian kesimpulan yang diambil hanya berdasarkan data yang dikumpulkan melalui penggunaan instrument secara tertulis. 
2. Penelitian ini juga memiliki keterbatasan dalam pengambilan sampel yang kurang luas untuk stasiun televisi yang ada di Ibu Kota Jakarta saja. Begitu pula untuk pengambilan sampel karyawan hanya mencakup beberapa devisi saja, karena mungkin dengan mencakup seluruh divisidari stasiun televisi dapat memberikan hasil yang lebih baik lagi. Divisi yang diambil sampelnya adalah divisi programming, divisiproduksi, dandivision air.

3. Pendistribusian kuesioner berpusat pada divisi yang pekerjanya didominasi oleh pria, sehingga jumlah responden yang mengisi kuesioner kebanyakan adalah pria sedangkan wanitanya hanya sebagian.

4. Pada penelitian ini hanya terbatas meneliti empat variabel saja, yaitu job insecurity terhadap keinginan untuk berpindah kerja dengan komitmen organisasional, dan kepuasan kerja sebagai variabel intervening.

5. Pada kuesioner yang dibagikan belum dicantumkan divisi tempat responden tersebut bekerja.

\section{Saran}

Saran atas penelitian yang telah dilakukan untuk selanjutnya adalah:

1. Untuk penelitan selanjutnya disarankan agar menggunakan metode lain yang dapat mengatasi kelemahan dalam metode yang dilakukan pada penelitian ini. Hasil penelitian yang lebih baik dapat diperoleh apabila tidak hanya berdasarkan hasil perolehan penyebaran kuesioner saja. Tetapi bias dengan melakukan wawancara secara langsung dan mendampingi responden dalam proses pengumpulan data padaresponden yang akan diteliti.

2. Pendistribusian sampel diperluas, tidak hanya untuk stasiun televisi yang ada di Ibu Kota Jakarta saja tetapi juga untuk seluruh stasiun televisi yang ada di Indonesia. Mengingat saat ini daerah-daerah di Indonesia sudah memiliki stasiun televisi lokal yang berdiri setiap masing-masing daerahnya

3. Penyebaran kuesioner sebaiknya dilakukan secara merata dan imbang untuk responden pria dan wanita. Sehingga diharapkan data yang diperoleh dapat mewakili kenyataan yang ada dalam suatu organisasi atau perusahaan.

4. Untuk penelitian selanjutnya diharapkan dapat menambahkan faktor-faktor lain yang dapat mempengaruhi keinginan berpindah kerja dari karyawan disuatu perusahaan atau organisasi. Salah satu variabel yang dapat dijadikan penelitian lainnya antara lain adalah kepuasan gaji, tingkat turnover pada karyawan atau budaya kerja.

5. Kuesioner pada penelitian selanjutnya diharapkan mencantumkan divisi tempat responden tersebut bekerja, sehingga data yang diperoleh dapat sesuai dengan yang diharapkan oleh peneliti.

\section{Referensi}

Abelson, M. A. 1987. Examination of Avoidable and Unavoidable Turnover. Journal of Applied Phsychology, 72: 382-386

Amirin, Tatang M. 2000. Menyusun Rencana Penelitian. Jakarta: Raja Grafindo Persada.

Utami, Intiyas , Nur Endah S. 2008. "Pengaruh Job Insecurity, Kepuasan Kerja dan Komitmen organisasional Terhadap Keinginan Berpindah Kerja", Accounting Coference, The $2^{\text {nd }}$ Accounting \& The $1^{\text {st }}$ Doctoral Colloquium 4-5 November 2008.

Dawes, John (2008), "Do Data Characteristics Change According to the number of scale points used? An experiment using 5-point, 7-point and 10-point scales," International Journal of Market Research 
Ghozali, Imam, Aplikasi Analisis Multivariate dengan Program SPSS, Semarang : Badan Penerbit Universitas Diponegoro, 2005.

Haryono, Ery. 2006. "Pengaruh Faktor Anteseden (Job Insecurity dan Monitoring) melalui Kinerja, Konflik Peran, dan Komitmen Organisasional (sebagai variabel intervening) terhadap Keinginan Pindah Auditor". Skripsi Program S1 Fakultas Ekonomi Universitas Kristen Satya Wacana (tidak dipublikasikan)

http://www.damandiri.or.id/file/frnsiskakorompisbab3.pdf 3 November 2010 http://statistik4life.blogspot.com/2009/12/blog-post.html 12 Desember 2010

Iriana, Prapti. Lilis Wijayanti dan Ion Listyorini. 2004. "Pengaruh Faktor Job Insecurity, Kepuasan Kerja sebagai Variabel Antara: Studi pada Dosen Tetap Perguruan Tinggi Swasta di Kotamadya Malang”. Jurnal Akuntansi Bisnis Manajemen Vol. 11 No. 2 pp. 120-141.

Kunia, Ratnawati. 2009. "Pengendalian Tindakan, Hasil, Personil, dan Kultur, Pengaruhnya terhadap Kepuasan Kerja dan Komitmen Organisasi, Jurnal Ilmu Akuntansi Vol. 1 No. 1 Desember 2009.

Lekatompessy, Jantje E. 2004. "Hubungan Profesionalisme dengan Konsekuensinya: Komitmen Organisasional, Kepuasan Kerja, Prestasi Kerja, dan Keinginan Berpindah, Jurnal Bisnis dan Akuntansi Vol. 5, No 1, April 2003, 69-84

Meyer, Jhon P, Natalie J. Allen, and Catherine A. Smith. 1993. "Commitment to Organizations and Occupation: Extensions and Test of A Three - Component Conceptualization". Jurnal of Applied Psychology, Vol. 78 No. 4

Mulyadi \& Johny Setyawan, Sistem Perancanaan dan Pengendalian Manajement, Sistem Pelipatgandaan Kinerja Perusahaan, Aditya Media, edisi 2, 2007.

Novliadi. Ferry. (2009). Hubungan Antara Persepsi Terhadap Organisasi Pembelajar dengan Job Insecurity Pada Karyawan. USU e-Repository. 2009

Pasewark, W. R and J. R. Strawser. (1996). The Determinants and Outcomes Associated With Job Insecurity in a Professional Accounting Environment, Behavioral Research in Accouting.

Robbins, Stephen P, Organizational Behavior, Concepts Controversies Application, Prentice Hall, 2007

Sekaran, Uma and Roger Bougie, Research Method for Business : A Skill Building Approach, West Sussex:John Wiley \& Sons, Inc, 2010.

Santoso, Singgih, Statistik Parametrik: Konsep dan Aplikasi dengan SPSS, Jakarta: PT Elex Media Komputindo,2010.

Suwandi, dan Nur Indriantoro. 1999, "Pengujian Model Turnover Pasewark danStrawser: Studi Empiris pada Lingkungan Akuntansi Publik", Jurnal Riset Akuntansi Indonesia.

Witasari. 2009. "Analisis Pengaruh Kepuasan Kerja dan Komitmen Organisasional Terhadap Turnover Intention (Studi Empiris pada Novotel Semarang)". Universitas Diponegoro

Widianita. 2009. "Pengaruh Komitmen Organisasi Dan Kepuasan Kerja Terhadap Keinginan Berpindah Kerja Pada Rumah Sakit Di Surakarta". Universitas Muhammadiyah Surakarta

Yulianti, Dian. 2009. "Pengaruh Komitment Organisasional Dalam Hubungan Antara Kepuasan Kerja dan Turnover Karyawan Bagian Penjualan", Universitas Muhammadiyah Surakarta. 